\title{
Edukasi Diversifikasi Pangan Skala Rumah Tangga pada Masa Pandemi Bagi Masyarakat Di Lingkungan Kevikepan Daerah Istimewa Yogyakarta
}

\author{
Leonie Margaretha Widya Pangestika*, Yuliana Reni Swasti, Fransiscus Sinung Pranata, LM Ekawati \\ Purwijantiningsih \\ Program Studi Biologi, Fakultas Teknobiologi, Universitas Atma Jaya Yogyakarta \\ *leonie.margaretha@uajy.ac.id
}

\begin{abstract}
Abstrak
Selama masa pandemi, terjadi peningkatan aktivitas budidaya tanaman sayur mayur dan ikan lele yang dilakukan secara mandiri oleh masyarakat di lingkungan Kevikepan Daerah Istimewa Yogyakarta (DIY). Hal tersebut menyebabkan tingginya hasil panen di lingkup rumah tangga. Diversifikasi pangan menjadi solusi yang dapat dilakukan untuk mengolah hasil panen secara optimal, sehingga akan tercipta ketahanan pangan bagi masingmasing keluarga. Edukasi diversifikasi pangan bertujuan meningkatkan pengetahuan masyarakat terhadap ragam pangan yang dapat dikembangkan dengan mudah di rumah, serta trik teknologi pengolahan pangan tersebut. Edukasi berupa kegiatan penyuluhan dilakukan secara daring dan dihadiri 27 peserta yang merupakan masyarakat di lingkungan Kevikepan DIY. Teknik pengolahan produk pangan didemonstrasikan melalui video pengolahan sayuran hijau menjadi sayur fermentasi, cabai menjadi bubuk cabai, dan ikan lele menjadi sambal ikan lele. Tingkat pengetahuan peserta diukur melalui pengerjaan pretest dan post test berdasarkan pertanyaan yang sama. Hasil analisis uji Wilcoxon Signed Rank membuktikan bahwa terdapat peningkatan skor yang signifikan setelah mengikuti kegiatan penyuluhan $(\mathrm{p}=0,004)$.
\end{abstract}

Kata kunci-bubuk cabai, diversifikasi pangan, sambal ikan lele, sayur fermentasi, skala rumah tangga

\section{Pendahuluan}

Peningkatan ketahanan pangan nasional perlu dibangun dari ketahanan pangan di skala rumah tangga. Ketahanan pangan skala rumah tangga memiliki makna yaitu setiap keluarga dapat memenuhi kebutuhan pangan secara mandiri (Sarjiyah, Samijo, dan Istiyanti, 2016). Pekarangan rumah merupakan area paling dekat yang dapat dimanfaatkan oleh rumah tangga untuk budidaya tanaman pangan, seperti sayuran dan buah-buahan. Pada area yang lebih luas, pekarangan juga dapat dimanfaatkan untuk budidaya komoditas perikanan dan peternakan (Ashari, Saptana, dan Purwantini, 2016; Rachman, Purwantini, dan Marisa, 2016; Sarjiyah dkk., 2016).

Pada masa pandemi, masyarakat di lingkungan Kevikepan DIY memperoleh bantuan berupa bibit sayur mayur, seperti sawi, kangkung dan ikan lele yang dapat dibudidayakan di area pekarangan rumah. Hal tersebut dapat mendukung program ketahanan pangan yang diupayakan oleh pemerintah sejak lama. Namun di sisi lain, komoditas seperti sayur dan ikan memiliki umur simpan yang cenderung singkat (Sari dan Hadiyanto, 2013). Apabila tidak termanfaatkan dengan maksimal, dapat menimbulkan persoalan baru yaitu penumpukan limbah rumah tangga. Oleh karena itu, upaya peningkatan ketahanan pangan melalui pemanfaatan lahan pekarangan perlu diimbangi dengan pengolahan pasca panen sehingga tercapai proses yang berkesinambungan.

Salah satu langkah strategis yang dapat dilakukan adalah diversifikasi pangan. Diversifikasi pangan merupakan upaya yang dapat dilakukan untuk meningkatkan keragaman jenis pangan yang dikonsumsi dengan kualitas baik (Elizabeth, 2011), yaitu pangan yang higienis, aman, dan bergizi. Diversifikasi pangan dapat memberikan pengalaman makan yang bervariasi bagi masyarakat serta memperkaya asupan nutrisi yang dibutuhkan oleh tubuh. 
Kondisi di lapangan menunjukkan bahwa pengetahuan masyarakat mengenai ragam olahan pangan, sanitasi dan higienis rumah tangga, serta keamanan pangan masih terbatas (Elizabeth, 2011). Hal tersebut menyebabkan implementasi diversifikasi pangan kurang berkembang. Selain itu, pengalaman, pengetahuan, ketrampilan, dan motivasi masyarakat dalam menggali dan memanfaatkan potensi sumber daya alam yang ada masih terbilang rendah (Suryani dkk., 2019). Masyarakat cenderung mengolah bahan sayur dan ikan lele menjadi masakan sederhana. Ketika hasil panen melimpah, keterbatasan pengetahuan mengenai ragam olahan pangan dapat menimbulkan kebosanan di tengah masyarakat. Oleh karena itu, perlu adanya upaya untuk meningkatkan pengetahuan masyarakat. Selain itu, masyarakat juga perlu dimotivasi untuk berinovasi dalam mengolah bahan pangan.

Penyuluhan adalah salah satu bentuk kegiatan bersifat edukasi yang dapat membantu meningkatkan pengetahuan masyarakat. Berdasarkan laporan terdahulu, kegiatan penyuluhan secara signifikan dapat meningkatkan tingkat pengetahuan masyarakat dari 48,48\% menjadi 84,84\% (Cahyaningsih, Wiedyaningsih, dan Kristina, 2013). Beberapa studi terdahulu lainnya juga telah membuktikan bahwa penyuluhan dapat meningkatkan pengetahuan masyarakat dalam berbagai bidang, seperti kesehatan dan lingkungan (Azhari, Muljono, dan Tjitropranoto, 2016; Helmi, Nengsih, dan Suganda, 2018). Oleh karena itu, kegiatan penyuluhan penting dilakukan untuk meningkatkan pengetahuan masyarakat mengenai ragam pengolahan pangan serta teknologi pengolahan pangan yang benar.

\section{Metode Pelaksanaan}

Upaya untuk meningkatkan pemahaman masyarakat dilakukan dengan metode pendidikan masyarakat berupa kegiatan penyuluhan. Peserta penyuluhan merupakan warga di Lingkungan Kevikepan DIY yang dibimbing oleh tim dosen minat studi Teknobio-Pangan Fakultas Teknobiologi, Universitas Atma Jaya Yogyakarta. Kegiatan dilaksanakan pada 13 Juli 2020 secara daring menggunakan platform Zoom Meeting. Karakteristik peserta penyuluhan berdasarkan jenis kelamin dan usia dapat dilihat pada Tabel 1 . Kegiatan penyuluhan diversifikasi pangan dihadiri oleh 27 peserta yang didominasi oleh perempuan (74\%). Peserta penyuluhan berasal dari berbagai grup usia dengan persentase terbesar berasal dari grup usia yang aktif bekerja, yaitu kurang dari 60 tahun (Farikha dan Ardyanto, 2017).

Tabel 1. Karakteristik Peserta Penyuluhan Berdasarkan Jenis Kelamin dan Usia (n=27)

\begin{tabular}{ccc}
\hline Karakteristik & $\begin{array}{c}\text { Frekuensi } \\
(\mathbf{n})\end{array}$ & $\begin{array}{c}\text { Persentase } \\
(\%)\end{array}$ \\
\hline Jenis Kelamin & & \\
$\quad$ Laki-laki & 7 & 26 \\
$\quad$ Perempuan & 20 & 74 \\
Usia & & \\
$\quad$ < 30 tahun & 5 & 19 \\
$31-40$ tahun & 4 & 15 \\
$41-50$ tahun & 9 & 33 \\
$51-60$ tahun & 6 & 22 \\
$>60$ tahun & 3 & 11 \\
\hline
\end{tabular}

Kegiatan penyuluhan dibagi menjadi 2 tahap yaitu persiapan dan pelaksanaan. Persiapan dilakukan dengan membuka registrasi menggunakan Google Form bagi masyarakat Kevikepan DIY yang ingin bergabung dalam kegiatan penyuluhan. Beberapa informasi yang dihimpun mengenai peserta antara lain, jenis kelamin, usia, frekuensi keikutsertaan dalam kegiatan penyuluhan, kesukaan terhadap pangan fermentasi (tipe pertanyaan : Ya atau Tidak), dan kepemilikan usaha produk pangan olahan (tipe pertanyaan : Ya, Tidak, memiliki usaha kurang dari atau lebih dari 5 tahun). Pangan fermentasi yang dimaksud pada kuisioner tidak merujuk pada pangan fermentasi tertentu secara spesifik. Informasi ini berfungsi untuk memetakan karakteristik peserta penyuluhan. Selain itu dilakukan persiapan alat bantu penyuluhan berupa video pengolahan produk pangan. Beberapa alat dan bahan yang diperlukan antara lain 1) handphone untuk mengambil foto, merekam video dan audio; 2) laptop dan aplikasi video editor untuk menyatukan dan melengkapi komponen video, seperti teks dan musik; 3) alat dan bahan yang dibutuhkan untuk mengolah sayur fermentasi, bubuk cabai, dan sambal ikan lele.

Tahap pelaksanaan terdiri atas beberapa sesi, yaitu: 1) pengerjaan pretest, 2) pemaparan materi mengenai ketahanan pangan keluarga dengan metode ceramah, 3) pemaparan materi mengenai diversifikasi pangan dengan 
metode ceramah serta penayangan video untuk mendemonstrasikan cara pengolahan sayur hijau, antara lain kangkung, kailan, caisim, pakcoy, petsai, cabai, dan ikan lele menjadi sayur fermentasi, bubuk cabai, dan sambal ikan lele, secara berurutan, 4) tanya jawab 5) pengerjaan post test.

Tahap pertama adalah pemberian pretest kepada seluruh peserta yang memuat 3 pertanyaan sederhana. Tipe pertanyaan yang diberikan adalah pilihan ganda dengan skor 5 untuk jawaban benar. Pertanyaan yang diberikan dapat dilihat pada Tabel 2.

Tabel 2. Pertanyaan pada pretest dan post test

\begin{tabular}{cl}
\hline No. & \multicolumn{1}{c}{ Pertanyaan $(\mathbf{P})$} \\
\hline 1. & Fungsi utama penggunaan garam dalam pembuatan sayur fermentasi \\
& adalah... \\
2. & Bakteri baik yang dapat memberi efek kesehatan bagi manusia disebut... \\
3. & Apa prinsip peningkatan umur simpan pada pembuatan bubuk cabai? \\
\hline
\end{tabular}

Tahap kedua adalah pemaparan materi mengenai ketahanan pangan keluarga. Pemaparan materi ini bertujuan memberikan informasi mengenai pentingnya ketahanan pangan di skala rumah tangga. Selain itu, memberi dorongan kepada peserta penyuluhan untuk dapat meningkatkan ragam olahan pangan yang dikonsumsi.

Tahapan ketiga adalah pemaparan mengenai diversifikasi pangan. Pemaparan ini memberikan informasi mengenai pengolahan yang dapat dilakukan dengan mudah di skala rumah tangga untuk sayuran hijau, cabai, dan ikan lele. Selain itu, disampaikan pula teknik pengolahan pangan yang tepat dengan mempertimbangkan aspek keamanan dan higienis pangan. Cara pengolahan ketiga jenis bahan pangan tersebut didemonstrasikan menggunakan video tutorial.

Tahap keempat yaitu sesi tanya jawab yang diakomodasi oleh moderator penyuluhan. Tahap kelima yaitu pengisian post test untuk mengukur pemahaman peserta setelah mengikuti penyuluhan. Post test diberikan dengan menyebarkan kuisioner online menggunakan Google Form. Tipe pertanyaan yang diberikan adalah pilihan ganda dengan skor 5 untuk jawaban benar. Pertanyaan yang digunakan sama dengan pertanyaan pada pre test (Tabel 2). Hasil penyuluhan digambarkan secara deskriptif dan dievaluasi dengan uji Wilcoxon Signed Rank menggunakan JASP untuk mengetahui tingkat pengetahuan peserta sebelum dan sesudah kegiatan penyuluhan melalui pengerjaan pretest dan post test.

\section{Hasil Dan Pembahasan}

\section{Diversifikasi pangan}

Pada kegiatan penyuluhan, masyarakat diedukasi mengenai ragam produk pangan yang dapat diolah dari sayur hijau, cabai, dan ikan lele. Dalam kehidupan sehari-sehari, pemanfaatan sayur hijau terbatas sebagai sayuran yang dimakan bersama dengan nasi. Sebagian masyarakat juga mengolah sayur hijau menjadi sayur asin melalui proses fermentasi. Dengan proses fermentasi yang sedikit berbeda, sayuran hijau juga dapat diolah menjadi sayur fermentasi yang menyerupai kimchi. Jenis sayur yang dapat dimanfaatkan antara lain pakcoy, caisim, kangkung, kailan, dan sawi putih. Hasil fermentasi dari sayuran tersebut memiliki rasa asam, sensasi segar, dan citarasa khas dari masing-masing jenis sayur. Dari segi nutrisi, sayur fermentasi kaya akan vitamin, mineral, serat, dan berbagai komponen fungsional (Park dkk., 2014). Keunggulan lain dari sayur fermentasi adalah kandungan probiotik yang bermanfaat bagi kesehatan dengan meningkatkan sistem imun tubuh (Patra dkk., 2016). Probiotik adalah mikroorganisme hidup yang ada di dalam produk pangan dan dapat memberi efek kesehatan. Probiotik sering juga disebut sebagai bakteri baik. Dengan demikian, inovasi pembuatan sayur fermentasi tidak hanya sebagai bentuk implementasi diversifikasi pangan tetapi juga memberi dampak positif bagi kesehatan masyarakat yang mengonsumsinya. Foto dari produk sayur fermentasi dapat dilihat pada Gambar 1.

Cabai, khususnya cabai rawit merupakan salah satu jenis produk hortikultura dengan tingkat permintaan yang tinggi, khususnya di Indonesia (Yanti, Susrusa, dan Listiadewi, 2019). Cabai mengandung vitamin C dalam jumlah tinggi, serta komponen bioaktif, capsaicin, yang memiliki beragam manfaat kesehatan, seperti pereda nyeri, antiinflamasi, anti-bakteri, anti-artritis (Chakrabarty, Islam, dan Islam, 2017). Umumnya cabai digunakan sebagai bumbu dalam masakan atau diolah menjadi sambal. Produk turunan cabai lainnya adalah bubuk cabai yang dibuat dengan metode pengeringan menggunakan oven (Saputro dan Susanto, 2016). Meskipun melalui proses pengeringan, bubuk cabai masih memiliki kandungan vitamin $\mathrm{C}$ dan capsaicin (Wiriya, Paiboon, dan Somchart, 
2009). Potensi pengolahan bubuk cabai antara lain dapat dimanfaatkan sebagai salah satu bahan dalam pembuatan sayur fermentasi serta dapat dijual secara komersial ke pasaran.

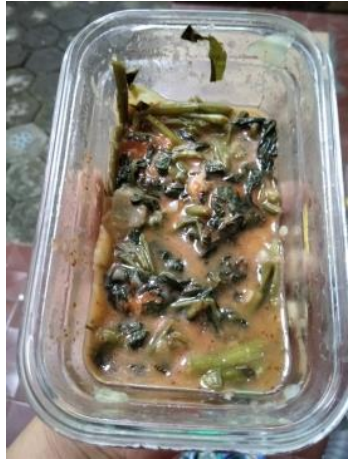

(a)

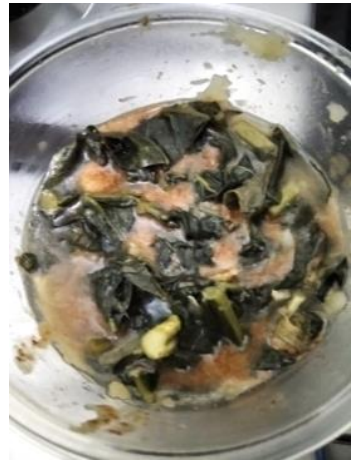

(b)

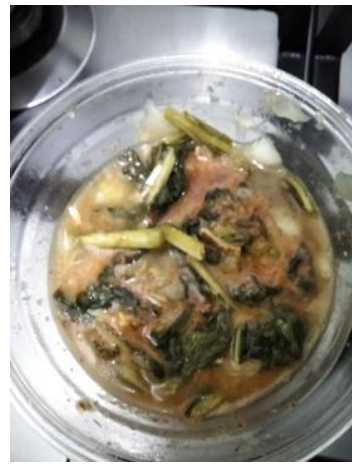

(c)

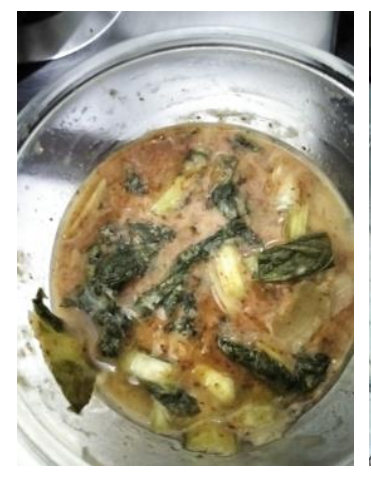

(d)

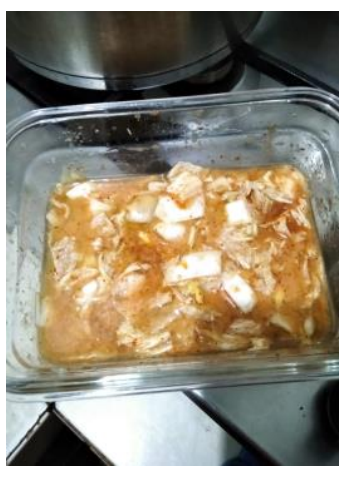

(e)

Gambar 1. Produk sayur fermentasi. (a) Kangkung fermentasi, (b) Kailan fermentasi, (c) Caisim fermentasi, (d) Pakcoy fermentasi, (e) Petsai fermentasi

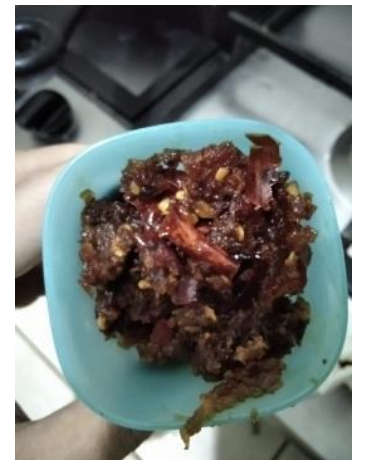

(a)

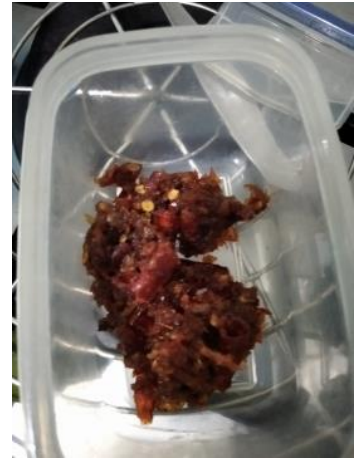

(b)

Gambar 2. Produk sambal ikan lele. (a) Sambal ikan lele hari ke-0, (b) Sambal ikan lele hari ke-7

Produk ketiga yang digagas melalui kegiatan ini adalah sambal ikan lele. Produk ini mengombinasikan pemanfaatan cabai dan ikan lele. Selain mudah untuk dibudidayakan, ikan lele tergolong dalam jenis pangan berprotein tinggi dan rendah lemak yaitu sekitar 17,7\% protein dan 0,95\% lemak (Nurilmala, Nurjanah, dan Utama, 2009). Dengan demikian, produk turunan ikan lele seperti sambal ikan lele dapat menjadi sumber protein. Saat ini telah berkembang berbagai jenis sambal yang dikombinasikan dengan ikan atau udang, bahkan telah dijual secara komersial. Pembuatan sambal ikan lele secara mandiri di rumah dapat menghasilkan produk yang lebih terjamin kebersihan dan kesegarannya. Keunggulan sambal ikan lele yang dikembangkan pada kegiatan ini adalah memiliki 
umur simpan yang lebih panjang dibanding bahan segarnya yaitu hingga 7 hari pada suhu refrigerasi $\left(5^{\circ} \mathrm{C}\right)$, tanpa adanya perubahan warna, rasa, tekstur, dan aroma. Foto produk sambal ikan lele dapat dilihat pada Gambar 2.

Dari segi peralatan dan cara pengolahan, pembuatan ketiga produk pangan tersebut tidak membutuhkan peralatan yang kompleks. Masyarakat dapat mengolahnya dengan menggunakan peralatan sederhana yang ada di rumah. Oleh karena itu, ketiga produk tersebut dapat dengan mudah diaplikasikan oleh peserta penyuluhan.

\section{Penyuluhan diversifikasi pangan}

Kegiatan penyuluhan diversifikasi pangan adalah pengalaman pertama bagi sebagian besar peserta. Sebanyak 20 orang peserta ( $74 \%$ dari total peserta) belum pernah mengikuti kegiatan penyuluhan dan hanya $7 \%$ yang pernah mengikuti kegiatan penyuluhan hingga lebih dari 5 kali. Materi dan informasi yang diperoleh melalui penyuluhan memberi bekal bagi masyarakat untuk berinovasi dengan bahan pangan yang ditemui sehari-hari. Hal tersebut dapat meningkatkan variasi konsumsi pangan masyarakat.

Salah satu produk yang digagas pada penyuluhan adalah sayur fermentasi. Sayur fermentasi memiliki citarasa yang khas, sehingga pada kegiatan ini dilakukan penelusuran mengenai kesukaan peserta terhadap pangan fermentasi. Mayoritas peserta yaitu sebanyak $89 \%$ menyukai pangan fermentasi. Tingkat kesukaan peserta terhadap pangan fermentasi menjadi faktor penting yang mendorong peserta untuk dapat mempraktikkan sendiri pembuatan sayur fermentasi. Hal tersebut dipengaruhi oleh preferensi personal terhadap produk pangan.

Melalui penyebaran kuisioner juga ditelusuri kepemilikan peserta terhadap usaha produk pangan olahan (Gambar 3). Sekitar 52\% dari total peserta tidak memiliki usaha produk pangan olahan. Hal tersebut menggambarkan bahwa mayoritas peserta memiliki kecenderungan hanya mengolah makanan yang dikonsumsi sehari-hari. Dengan mengikuti penyuluhan, peserta dapat memperkaya pengetahuan mengenai ragam pangan yang dapat diaplikasikan di rumah, serta meningkatkan motivasi peserta untuk memanfaatkan bahan pangan dengan optimal. Selain itu, materi yang disampaikan dapat membekali sebagian peserta (8 orang; 29\%) yang memiliki rencana untuk membuka usaha produk pangan olahan.

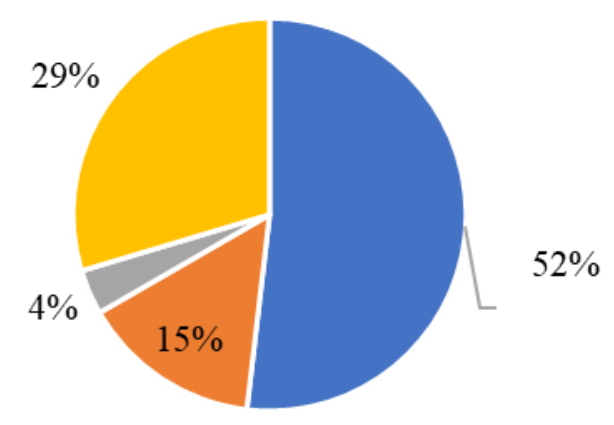

$\square$ Tidak $\square$ Ya, 1-5 tahun $\square$ Ya, lebih dari 5 tahun $\square$ Akan

Gambar 3. Kepemilikan usaha produk pangan olahan

Sebelum penyuluhan, peserta diberi 3 pertanyaan sederhana untuk menguji pengetahuan mengenai teknologi pengolahan pangan. Tingkat pengetahuan masyarakat pada saat pre test dapat dilihat pada Tabel 2. Sebelum penyuluhan, sebanyak 9 peserta $(33,3 \%)$ memberi jawaban yang salah pada pertanyaan 1 . Pemahaman peserta yaitu garam yang digunakan saat pembuatan sayur fermentasi berfungsi untuk memberi rasa atau dapat mengubah warna. Dalam aplikasi pembuatan sayur fermentasi, garam memiliki fungsi penting yaitu menghambat pertumbuhan mikroba patogen dan pembusuk (antimikroba) (Patra dkk., 2016; Wijnker dan Koop, 2006). Makanan yang ditambah garam, khususnya dalam jumlah tinggi, memiliki umur simpan yang lebih panjang. Oleh karena itu sayur fermentasi masih dapat dikonsumsi hingga 5 hari setelah fermentasi dengan kondisi penyimpanan pada suhu rendah $\left( \pm 5^{\circ} \mathrm{C}\right)$.

Berdasarkan hasil pre test, sebanyak 25 peserta $(92,6 \%)$ telah memiliki pemahaman yang benar untuk pertanyaan ke 2 yaitu mengenai jenis bakteri yang bermanfaat bagi kesehatan tubuh. Hanya 2 peserta yang memberi jawaban salah dengan memilih patogen sebagai bakteri yang bermanfaat bagi kesehatan. Bakteri patogen adalah bakteri 
yang dapat menyebabkan penyakit dan erat kaitannya dengan makanan yang dikonsumsi. Oleh karena itu, penting untuk mengetahui dan mempraktikkan sanitasi dan prinsip keamanan pangan ketika mengolah bahan pangan.

Pertanyaan ke 3 membahas teknologi pengolahan cabai menjadi bubuk cabai. Bubuk cabai dihasilkan melalui proses pengeringan. Pengeringan merupakan peningkatan umur simpan dengan cara mengurangi kadar air pada bahan pangan (Saputro dan Susanto, 2016). Hasil pre test menunjukkan 26\% peserta memiliki pemahaman yang salah dimana bubuk cabai dibuat melalui proses sterilisasi. Sterilisasi merupakan produk pemanasan untuk membunuh bakteri yang umumnya dilakukan untuk produk seperti susu.

Tabel 2. Tingkat Pengetahuan Peserta pada saat Pre Test

\begin{tabular}{ccccc}
\hline & \multicolumn{2}{c}{ Benar } & \multicolumn{2}{c}{ Salah } \\
\cline { 2 - 5 } $\mathrm{P}$ & $\begin{array}{c}\text { Frekuensi } \\
(\mathrm{n})\end{array}$ & $\begin{array}{c}\text { Persentase } \\
(\%)\end{array}$ & $\begin{array}{c}\text { Frekuensi } \\
(\mathrm{n})\end{array}$ & $\begin{array}{c}\text { Persentase } \\
(\%)\end{array}$ \\
\hline 1 & 18 & 66,7 & 9 & 33,3 \\
2 & 25 & 92,6 & 2 & 7,4 \\
3 & 19 & 70,4 & 8 & 29,6 \\
\hline
\end{tabular}

Keterangan; $\mathrm{P}=$ Pertanyaan

Edukasi menjadi penting untuk dilakukan guna membuka wawasan dan meningkatkan pengetahuan peserta, tidak hanya mengenai ragam produk pangan, tetapi juga trik teknologi pengolahan pangan yang benar. Beberapa trik teknik pengolahan pangan yang disampaikan antara lain : 1) Pada pembuatan sayur fermentasi, bahan lain selain sayuran yang digunakan untuk pengolahan perlu dicelupkan dalam air mendidih untuk mencegah adanya bakteri yang tidak diinginkan selama fermentasi; 2) Tahap kritis pada pembuatan sambal ikan lele adalah pemasakan bahan sambal baik sebelum dan sesudah penghalusan; 3) Setiap peralatan yang digunakan perlu dalam keadaan bersih dan steril; 4) Sayur fermentasi disimpan pada suhu rendah untuk memperpanjang umur simpan dan menjamin keamanan pangannya.

Setelah pemaparan mengenai diversifikasi pangan, dibuka sesi tanya jawab untuk memfasilitasi pertanyaan dari peserta. Sesi tanya jawab bermanfaat untuk meningkatkan pemahaman peserta mengenai materi yang disampaikan. Sebagian pertanyaan yang diajukan berkaitan dengan produk sayur fermentasi. Hal tersebut menunjukkan ketertarikan peserta terhadap sayur fermentasi. Beberapa pertanyaan yang diajukan antara lain: 1) perbedaan antara kimchi dengan asinan Bogor dari segi nutrisi; 2) penggunaan cabai atau bubuk cabai dalam pembuatan sayur fermentasi; 3) cara mengurangi bau dari makanan hasil fermentasi; 4) umur simpan kimchi; 5) cara membuat bakteri probiotik. Pertanyaan yang diajukan kemudian direspon secara langsung oleh narasumber.

Kandungan vitamin pada produk pangan fermentasi bervariasi tergantung pada bahan baku yang digunakan. Beberapa jenis bakteri dapat mensintesis vitamin B khususnya vitamin B12. Asinan Bogor dibuat dari berbagai sayur dan buah, sehingga kandungan nutrisinya berbeda dengan kimchi. Namun, penambahan produk fermentasi kedelai pada pembuatan kimchi meningkatkan kandungan bakteri probiotik dibanding pada pembuatan asinan yang hanya menggunakan cuka dan sedikit garam.

Bubuk cabai atau cabai tidak harus digunakan apabila peserta tidak menyukai makanan pedas. Meskipun demikian, produk yang dihasilkan tidak dapat disebut sebagai kimchi. Hal tersebut disebabkan karena salah satu bahan pembuatan kimchi adalah bubuk cabai atau cabai.

Secara umum, pangan fermentasi memiliki aroma asam. Yang dapat dilakukan untuk mengurangi aroma asam pada pangan fermentasi adalah dengan menambahkan gula pasir. Meskipun demikian, proses pengolahan yang tepat tidak akan menghasilkan aroma asam yang menyengat.

Setelah fermentasi selama 2 hari, disarankan sayur fermentasi langsung disimpan di dalam kulkas. Pada kondisi penyimpanan suhu rendah, sayur fermentasi masih dapat dikonsumsi hingga 5 hari untuk mempertahankan bakteri probiotik tetap ada dalam jumlah yang cukup untuk dapat memberi manfaat kesehatan. Namun, umur simpan juga sangat dipengaruhi oleh proses pengolahan yang dilakukan. Oleh karena itu, penting untuk memastikan setiap alat yang digunakan sudah steril sehingga tidak menyebabkan adanya pertumbuhan bakteri pembusuk yang tidak diinginkan.

Pada dasarnya bahan pangan mengandung mikroorganisme yang baik atau buruk secara alami. Pengolahan pangan dapat bertujuan untuk membunuh atau meningkatkan pertumbuhan bakteri tertentu. Dalam kasus pembuatan pangan fermentasi, pertumbuhan bakteri probiotik dapat didorong dengan penambahan garam, asam, atau direndam untuk mengurangi oksigen dan membunuh bakteri patogen. Kondisi tersebut kemudian memberi 
kesempatan bakteri probiotik yang dapat tumbuh pada kondisi garam tinggi, seperti pada pembuatan sayur fermentasi.

Setelah mengikuti kegiatan penyuluhan, tingkat pengetahuan peserta terhadap pertanyaan yang sama diuji melalui pengerjaan post test. Hasil pengujian tingkat pengetahuan peserta pada saat post test dapat dilihat pada Tabel 3. Hasil post test menunjukkan bahwa persentase jawaban benar peserta mencapai lebih dari $85 \%$ untuk ketiga pertanyaan setelah mengikuti kegiatan penyuluhan. Persentase jawaban benar untuk pertanyaan 1 dan 2 mencapai $96,3 \%$..

Tabel 3. Tingkat Pengetahuan Peserta pada saat Post Test

\begin{tabular}{ccccc}
\hline & \multicolumn{2}{c}{ Benar } & \multicolumn{2}{c}{ Salah } \\
\cline { 2 - 5 } $\mathrm{P}$ & $\begin{array}{c}\text { Frekuensi } \\
(\mathrm{n})\end{array}$ & $\begin{array}{c}\text { Persentase } \\
(\%)\end{array}$ & $\begin{array}{c}\text { Frekuensi } \\
(\mathrm{n})\end{array}$ & $\begin{array}{c}\text { Persentase } \\
(\%)\end{array}$ \\
\hline 1 & 26 & 96,3 & 1 & 3,7 \\
2 & 26 & 96,3 & 1 & 3,7 \\
3 & 24 & 88,8 & 3 & 11,1 \\
\hline
\end{tabular}

Keterangan: $\mathrm{P}=$ Pertanyaan

Peningkatan total skor peserta dapat dilihat pada Gambar 4. Setelah mengikuti kegiatan penyuluhan, terdapat peningkatan perolehan total skor sempurna (15/15) dari 13 peserta saat pre test menjadi 23 saat post test. Sebaliknya, terjadi penurunan jumlah peserta dengan skor 5 dan 10 pada post test. Hal tersebut menunjukkan bahwa penyuluhan dapat mengedukasi masyarakat mengenai teknologi pengolahan pangan

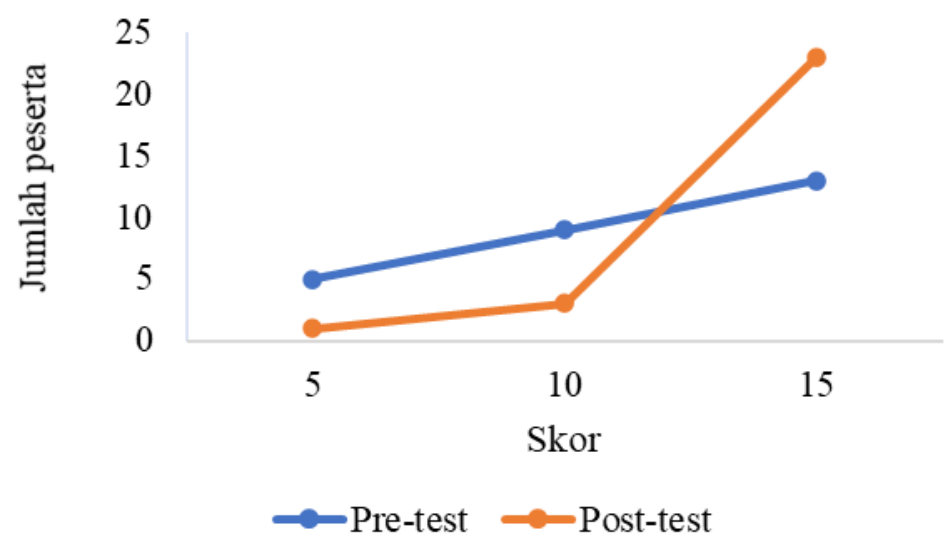

Gambar 4. Hasil Penilaian Pre test dan Post Test

Peningkatan skor dibuktikan juga melalui analisis statistik dengan uji Wilcoxon Signed Rank. Parameter yang digunakan untuk uji tersebut adalah skor dari masing-masing peserta, sebelum penyuluhan (pre-test) dan sesudah penyuluhan (post test). Hasil analisis dinyatakan melalui nilai $\mathrm{p}=0,002(\alpha=0,05)$ yang menunjukkan bahwa skor post test signifikan lebih tinggi dibanding dengan skor pre-test (Tabel 4), dimana mean dari pre-test dan post test secara berurutan, yaitu 11,5 dan 14,1.

Tabel 4. Hasil analisis dengan uji Wilcoxon Signed Rank

\begin{tabular}{cccc}
\hline Measure 1 & Measure 2 & W & $\mathrm{p}$ \\
\hline Pre-test & Post test & 0,000 & 0,002 \\
\hline
\end{tabular}

Peningkatan pengetahuan peserta setelah mengikuti kegiatan penyuluhan juga dilaporkan pada beberapa studi terdahulu (Cahyaningsih dkk., 2013; Simamora dan Saragih, 2019). Pelaksanaan kegiatan penyuluhan ini menjadi sejalan dengan implementasi Peraturan Pemerintah tentang Ketahanan Pangan No. 68 tahun 2002 pasal 9 ayat 2 yang menjelaskan bahwa upaya peningkatan kesadaran dan pengetahuan masyarakat perlu dilakukan untuk mendorong pelaksanaan kegiatan diversifikasi pangan oleh masyarakat. Peningkatan pengetahuan peserta didukung juga oleh metode penyampaian materi dengan video yang dapat memberikan penjelasan secara audio visual sehingga peserta dapat memiliki gambaran yang lebih jelas mengenai cara pembuatan produk pangan. Studi 
terdahulu menyampaikan bahwa penggunaan video ketika penyuluhan dapat meningkatkan pengetahuan dan partisipasi peserta (Rahmawati, Sudargo, dan Paramastri, 2007; Simamora dan Saragih, 2019).

\section{Kesimpulan}

Edukasi melalui kegiatan penyuluhan dapat meningkatkan pengetahuan masyarakat mengenai ragam pengolahan pangan dan teknologi pengolahan yang benar. Hal tersebut menjadi modal awal bagi masyarakat dalam meningkatkan keragaman pangan yang dikonsumsi. Diversifikasi pangan yang diimplementasikan oleh masyarakat di rumah masing-masing dapat menciptakan ketahanan pangan di skala rumah tangga. Dalam rangka menjamin keberlanjutan program pengabdian masyarakat, perlu dilakukan monitoring dan evaluasi berkelanjutan serta dapat pula dilakukan pengembangan menjadi unit usaha oleh kelompok masyarakat.

\section{Daftar Pustaka}

Ashari, N., Saptana, N., \& Purwantini, T. B. (2016). Potensi dan Prospek Pemanfaatan Lahan Pekarangan untuk Mendukung Ketahanan Pangan. Forum Penelitian Agro Ekonomi, 30(1), 13. https://doi.org/10.21082/fae.v30n1.2012.13-30

Azhari, R., Muljono, P., \& Tjitropranoto, P. (2016). Peran Penyuluh dalam Peningkatan Diversifikasi Pangan Rumah Tangga. Jurnal Agro Ekonomi, 31(2), 181. https://doi.org/10.21082/jae.v31n2.2013.181-198

Cahyaningsih, I., Wiedyaningsih, C., \& Kristina, S. A. (2013). Pengaruh Penyuluhan terhadap Tingkat Pengetahuan Masyarakat tentang Analgetik di Kecamatan Cangkringan Sleman. Mutiara Medika, 13(2), 98104. https://journal.umy.ac.id/index.php/mm/article/view/1060

Chakrabarty, S., Islam, A. K. M. M., \& Islam, A. K. M. A. (2017). Nutritional Benefits and Pharmaceutical Potentialities of Chili: A Review. Fundamental and Applied Agriculture, 2(2), 227-232. https://www.researchgate.net/publication/316716843_Nutritional_Benefits_and_Pharmaceutical_Potentialitie s_of_Chili_A_Review

Elizabeth, R. (2011). Strategi Pencapaian Diversifikasi dan Kemandirian Pangan: Antara Harapan dan Kenyataan. Iptek Tanaman Pangan, 6(2), 230-242. http://pangan.litbang.pertanian.go.id/files/08-roosganda.pdf

Farikha, R. R. P., \& Ardyanto, D. (2017). HUBUNGAN STATUS GIZI, KARAKTERISTIK INDIVIDU DENGAN PRODUKTIVITAS PEKERJA SORTING DAN PACKING. The Indonesian Journal of Occupational Safety and Health, 5(1), 71. https://doi.org/10.20473/ijosh.v5i1. 2016.71-80

Helmi, H., Nengsih, Y. K., \& Suganda, V. A. (2018). Peningkatan kepedulian lingkungan melalui pembinaan penerapan sistem 3R (reduce, reuse, recycle). JPPM (Jurnal Pendidikan Dan Pemberdayaan Masyarakat), 5(1), 1-8. https://doi.org/10.21831/jppm.v5i1.16861

Nurilmala, M., Nurjanah, \& Utama, R. H. (2009). Kemunduran mutu ikan lele dumbo (Clarias gariepinus) pada Penyimpanan Suhu Chilling dengan Perlakuan Cara Mati. Jurnal Pengolahan Hasil Perikanan Indonesia, XII(1), 1-16. https://journal.ipb.ac.id/index.php/jphpi/article/view/883

Park, K.-Y., Jeong, J.-K., Lee, Y.-E., \& Daily, J. W. (2014). Health Benefits of Kimchi (Korean Fermented Vegetables) as a Probiotic Food. Journal of Medicinal Food, 17(1), 6-20. https://doi.org/10.1089/jmf.2013.3083

Patra, J. K., Das, G., Paramithiotis, S., \& Shin, H.-S. (2016). Kimchi and Other Widely Consumed Traditional Fermented Foods of Korea: A Review. Frontiers in Microbiology, 7(SEP), 1-15. https://doi.org/10.3389/fmicb.2016.01493

Rachman, H. P. S., Purwantini, T. B., \& Marisa, Y. (2016). Prospek Diversifikasi Usaha Rumah Tangga dalam Mendukung Ketahanan Pangan dan Penanggulangan Kemiskinan. Forum Penelitian Agro Ekonomi, 24(1), 1. https://doi.org/10.21082/fae.v24n1.2006.1-13

Rahmawati, I., Sudargo, T., \& Paramastri, I. (2007). Pengaruh penyuluhan dengan media audio visual terhadap peningkatan pengetahuan, sikap dan perilaku ibu balita gizi kurang dan buruk di Kabupaten Kotawaringin Barat Propinsi Kalimantan Tengah. Jurnal Gizi Klinik Indonesia, 4(2), 69. https://doi.org/10.22146/ijcn.17478

Saputro, M. A. P., \& Susanto, W. H. (2016). Pembuatan Bubuk Cabai Rawit ( Kajian Konsentrasi Kalsium 
Propionat dan Lama Waktu Perebusan terhadap Kualitas Produk ). Jurnal Pangan Dan Agroindustri, 4(1), 62-71. https://jpa.ub.ac.id/index.php/jpa/article/viewFile/306/317

Sari, D. ., \& Hadiyanto. (2013). Teknologi dan Metode Penyimpanan Makanan Sebagai Upaya Memperpanjang Shelf Life. Jurnal Aplikasi Teknologi Pangan, $2(2), \quad 52$. http://www.jatp.ift.or.id/index.php/jatp/article/view/109

Sarjiyah, S., Samijo, G. S., \& Istiyanti, E. (2016). Mewujudkan Desa Mandiri Pangan Melalui Pengelolaan Pekarangan. BERDIKARI: Jurnal Inovasi Dan Penerapan Ipteks, 4(1), 13-22. https://doi.org/10.18196/bdr.412

Simamora, R. H., \& Saragih, E. (2019). Penyuluhan kesehatan terhadap masyarakat: Perawatan penderita asam urat dengan media audiovisual. JPPM (Jurnal Pendidikan Dan Pemberdayaan Masyarakat), 6(1), 24-31. https://doi.org/10.21831/jppm.v6i1.20719

Suryani, D., Kurniawan, D., Melizan, D. S., \& Putra, G. (2019). Pemberdayaan masyarakat Dusun Jaten, Mrico dan Bruno 1 untuk meningkatkan ketahanan pangan dengan pemanfaatan potensi lokal. 3(1), 39-44. http://journal2.uad.ac.id/index.php/jpmuad/article/view/608

Wijnker, J. J., \& Koop, G. (2006). Antimicrobial properties of salt ( $\mathrm{NaCl}$ ) used for the preservation of natural casings FOOD Antimicrobial properties of salt ( $\mathrm{NaCl}$ ) used for the preservation of natural casings. January 2018. https://doi.org/10.1016/j.fm.2005.11.004

Wiriya, P., Paiboon, T., \& Somchart, S. (2009). Effect of drying air temperature and chemical pretreatments on quality of dried chilli. International Food Research Journal, 16, 441-454. http://www.ifrj.upm.edu.my/16 (3) 2009/15[1] Wiriya.pdf

Yanti, N. M. S. W., Susrusa, K. B., \& Listiadewi, I. A. (2019). Faktor-faktor yang Mempengaruhi Permintaan Konsumen terhadap Cabai Rawit di Kota Denpasar Provinsi Bali. Jurnal Agribisnis Dan Agrowisata (Journal of Agribusiness and Agritourism), 8(2), 165-174. https://doi.org/10.24843/JAA.2019.v08.i02.p05 